\title{
Muscle Biopsy
}

National Cancer Institute

\section{Source}

National Cancer Institute. Muscle Biopsy. NCI Thesaurus. Code C51895.

Removal of tissue from the muscle, for microscopic examination. 